Original Paper

\title{
電子材料用高耐久性白金粉末およびペーストの開発
}

\section{Development of Pt Particles and Pastes with High Thermal Durability for Electronic Material}

\author{
村橋 大輔, ${ }^{a}$ 富田 秀幸, ${ }^{a}$ 飯田 典孝, ${ }^{a}$ 長井 $\quad$ 淳, $^{b}$ 中山 和尊 ${ }^{b}$ \\ Daisuke Murahashi, Hideyuki Tomita, Noritaka Iida, Atsushi Nagai, Kazutaka Nakayama
}

\begin{abstract}
Received 19 May 2006 ; Accepted 27 June 2006
Platinum ( $\mathrm{Pt}$ ) particles with high thermal durability are required for ceramic electrodes. In this work, spherical Pt particles coated with $\mathrm{Al}_{2} \mathrm{O}_{3}$ were prepared by coating pure $\mathrm{Pt}$ particles with Aluminum (Al) chelate followed by heat- treatment at $700{ }^{\circ} \mathrm{C}$. The thermal-gravimetric analysis of pure Pt particles and coated $\mathrm{Pt}$ particles showed that the weight decrease of coated particles is small compared to pure $\mathrm{Pt}$ particles. Thermal durability of an electrode made from the Pt particles was measured by repeating heat treatment at $1500{ }^{\circ} \mathrm{C}$. The rate of change in the electrical resistance of an electrode prepared from $\mathrm{Al}-$ coated Pt particles was lower than that of the electrode prepared from pure Pt particles.
\end{abstract}

Keywords : Platinum, Particle, Chelate, Coating, Heat- treating

\section{1. 緒 言}

電子材料の分野では，一般に白金粉末は，アルミ ナ，ジルコニア等のセラミック基板上に厚膜導体用白 金ペーストとして塗布，焼成されるなどの方法を用い て, 電極, ヒータ一，回路の形成に用いられる ${ }^{1 \sim 3)}$ 。 白金ペーストは焼成温度が高温の場合，例えば 1000 ${ }^{\circ} \mathrm{C}$ 以上になると電極焼成膜中に空隙等が多く発生 し，剥離，異常収縮等の構造欠陥が生じやすくなる。 その結果, 電極が断線しやすくなり，白金ペーストが 用いられているセラミック部品の耐久性が低下してし まうといった欠点があった。この空隙, 剥離等が起こ る原因は白金粉末特性に起因すると考えられる。白金 粉末は一般的に液相還元法4.5) で作製される。液相還 元法とは，塩化白金酸水溶液などの金属錯体溶液に

aノリタケ機材株式会社 技術部

（テ470-0293 愛知県西加茂郡三好町大字三好字東山320-3)

TEL 0561-34-4906

Technical Department, Noritake Kizai Co., Ltd.

(320-3, Higashiyama, Miyoshi, Aichi 470-0293, Japan)

$\mathrm{b}$ (株) ノリタケカンパニーリミテド 開発・技術本部

（テ451-8501 愛知県名古屋市西区則武新町 3丁目 1-36）

TEL 052-561-9866

Development \& Engineering Headquarter, Noritake Co., Ltd.

(3-1-36, Noritake-Shinmachi, Nagoya 451-8501, Japan)
種々の還元剂を投入することで粉末を得る方法であ る。液相還元法で得られた白金粉末は一般的に粒度分 布の均一性に優れるが, 真比重が低く低結晶性でポー ラスな多結晶粉末である場合が多い。ポーラスである ため多量のガスを吸着しやすい性質をもっておりここ の粉末を用いて作製される白金ぺーストは焼成途中で ガス脱離が起こる。そのガスの影響で，焼成時に発 泡, 歪み等が起き，焼成膜の連続性が損なわれ上述の ような問題が起こると考えられている。これに対し， 前処理として粉末に $500{ }^{\circ} \mathrm{C}$ 以上の温度で熱処理を行 うと，吸着ガスは脱離し，また粒子内部で粒成長が起 き，結晶性が高まり緻密質になるため，再度ガスが吸 着することは少なくなる。従って，上述のような不 具合は減少する。しかし，通常の熱処理方法では白 金粉末のネッキングが生じ分散不良となるため，焼 成膜が緻密化せず上述用途としての効果が期待でき なくなる。また，熱処理以外のアトマイズ法や噴霧 熱分解法 ${ }^{6}$ ７)では，粒子が高温場で生成するため粒子 内部まで燒結が進行するので脱離ガスの問題はなく なるが，均一な粒径を得ることが困難である。そこ で本研究では，白金粉末表面に金属キレート化合物 を均一に被覆させ，白金粉末同士のネッキングを抑 制させた状態で熱処理を行った。それにより，白金粉 
Table 1 Test Pt powder

\begin{tabular}{c|c|c|c|c|c|c|c|c|c}
\hline $\begin{array}{c}\text { Powder } \\
\text { samples }\end{array}$ & $\begin{array}{c}\text { Non-treated } \\
\text { precipitated) }\end{array}$ & $\mathrm{T}-1$ & $\mathrm{~T}-2$ & $\mathrm{~T}-3$ & $\mathrm{R}-1$ & $\mathrm{R}-2$ & $\mathrm{R}-3$ & $\mathrm{R}-4$ \\
\hline $\begin{array}{c}\text { Heat- treated } \\
\text { method }\end{array}$ & - & \multicolumn{2}{|c|}{$\begin{array}{c}\text { Chelate-coated } \\
\text { and Heat-treated }\end{array}$} & \multicolumn{3}{|c|}{ Standard Heat-treated } \\
\hline $\begin{array}{c}\text { Heat- treated } \\
\text { temperature }\end{array}$ & - & $400^{\circ} \mathrm{C}$ & $600^{\circ} \mathrm{C}$ & $700^{\circ} \mathrm{C}$ & $200^{\circ} \mathrm{C}$ & $400^{\circ} \mathrm{C}$ & $600^{\circ} \mathrm{C}$ & $700^{\circ} \mathrm{C}$ \\
\hline $\begin{array}{c}\mathrm{Al}_{2} \mathrm{O}_{3} \text { Coating } \\
\text { amount }\end{array}$ & - & \multicolumn{2}{|c|}{$0.5 \mathrm{wt} \%(/ \mathrm{Pt})$} & \multicolumn{4}{|c}{-} \\
\hline
\end{tabular}

末の分散性を維持しつつ, 高結晶でガス脱離の抑制 された白金粉末を得た。さらに，その粉末を用いる ことで，高温での耐久性の高い白金ペーストを開発 することに成功した。以下にその結果について報告 する。

\section{2. 実験}

\section{1 キレート被覆熱処理白金粉末の作製方法}

\section{1.1 原料白金粉末の試作}

まず，熱処理白金粉末を製造するための出発原料と なる原料白金粉末（以下「未熱処理品」と呼ぶ）を試 作した。合成の出発原料には塩化白金酸水溶液を用 い, 還元剤に水加ヒドラジン溶液を用いて，液相還元 法にて平均粒子径 $0.8 \mu \mathrm{m}$ の白金粉末を得た。

\section{1.2 単粁に熱処理する方法での熱処理白金粉 末の試作}

熱処理方法での比較例となる「キレート被覆せず， 単純に熱処理した白金粉末」(以下「通常熱処理品」 と呼ぶ）を試作した。原料となる液相還元法白金粉末 を所定量計量し，バッチ式焼成炉にて各温度 $\left(200^{\circ} \mathrm{C}\right.$, $400^{\circ} \mathrm{C}, 600^{\circ} \mathrm{C}, 700^{\circ} \mathrm{C}$ ) まで昇温速度 $5^{\circ} \mathrm{C} / \mathrm{min}$, 保持 時間 $10 \mathrm{~min}$ の焼成スケジュールにて熱処理を施し， \# 200 のナイロンメッシュでふるいを行い試料粉末 を得た。

\section{1.3 キレート被覆熱処理白金粉末の試作}

Fig. 1 に，プロセスフローを示す。金属キレート化 合物のキシレン溶液と液相還元法白金粉末を摖拌混合 し, 湯浴上で減圧乾燥し，金属キレートを白金粒子上

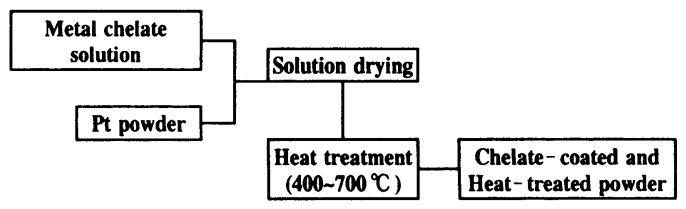

Fig. 1 Chelate-coated and heat-treated process
に被覆する。乾燥物を解砕後, 大気中で熱処理を行っ た。本研究では金属キレートにアルミニウムキレート を使用した。その結果, 熱処理後にはアルミナが白金 粒子表面を被覆していると考えられる。

テストサンプル内容を Table 1 に示す。熱処理温度 は $400{ }^{\circ} \mathrm{C}, 600{ }^{\circ} \mathrm{C}, 700{ }^{\circ} \mathrm{C}$ であり, 熱処理方法は通常 熱処理品の場合と同じである。

\section{2 粉末特性評価方法}

\section{2.1 分散性評価方法}

SEM を用いて白金粒子の粒径ならびに形状の観 察を行った。レーザ一回折式粒度分布測定装置 （HORIBA LA-500）を用いて白金粉末の粒度分布測 定を行った。また，タップ密度測定や比表面積測定も 行い，各粉末サンプルの分散性を評価した。

\section{2.2 結晶性評価方法}

$\mathrm{X}$ 線回折装置 (XRD) を用いて白金粉末の結晶子径 の測定を行った。ここで結晶子とは，一つの白金粉末 微粒子を構成する微細結晶のことをいう。結晶子の大 きさはX線回折チャートの強度ピークの半值幅を求め Scherrer の式より算出される値とした。

また，示差熱天秤 (TG) (Rigaku TG-8120) にて 白金粉末を $30{ }^{\circ} \mathrm{C} \sim 1200{ }^{\circ} \mathrm{C}$ まで加熱したときの減量 損失分を測定し，これをガス脱離による減量分と近 似的に判断し，ガス吸着性を評価した。また，全自 動真密度測定装置を用いて白金粉末の真比重を測定 した。

\section{3 ペースト特性評価方法}

白金電極は電子材料分野において，製造時または使 用時に特に高温にさらされる部品に使用される。白 金電極の高温耐久性を確認するため，液相還元法で 合成した未熱処理白金粉末と，それを元に作られた 通常熱処理 Pt 粉末, キレート被覆熱処理 Pt 粉末の 3 種の白金粉末を, それぞれエチルセルロース, ター ピネオールと混練することで，テストペーストを作製 した。 
Table 2 Test pastes

\begin{tabular}{c|c|c|c}
\hline Paste samples & Paste T-1 & Paste T-2 & Paste T-3 \\
\hline Pt powders & $\begin{array}{c}\text { Non-treated Pt } \\
\text { (precipitated) }\end{array}$ & $\begin{array}{c}\text { Standard Heat-treated } \\
\text { (Treated temp. } 600{ }^{\circ} \mathrm{C} \text { ) }\end{array}$ & $\begin{array}{c}\text { Chelate-coated and } \\
\text { Heat-treated } \\
\text { (Treated temp. } 600{ }^{\circ} \mathrm{C} \text { ) }\end{array}$ \\
\hline Resin & Ethyl cellulose & Ethyl cellulose & Ethyl cellulose \\
\hline Solvent & Terpineol & Terpineol & Terpineol \\
\hline
\end{tabular}

これらのテストペーストをアルミナ基板上にスク リーン印刷し，焼成することによって白金電極膜を形 成した。そして耐久性評価のために，作製した電極膜 に加熱処理（1500 ${ }^{\circ} \mathrm{C} \times 1 \mathrm{~h} ）$ を繰り返し施した時の抵 抗值变化率を測定した。この評価試験は，実際の電子 部品製造時における繰り返し加熱による耐久性，及び その部品の高温使用時における耐久性を模擬的に評 価するためのものである。1 回あたりの加熱処理条件 は $1500^{\circ} \mathrm{C} \times 1 \mathrm{~h}$ とした。1 回の加熱処理が終了する たびに電極の雨端間の抵抗值を測定し，その值を形成 直後の抵抗值で割って百分率で表し，抵抗值変化率と した。焼成後の膜厚が $4 \mu \mathrm{m}$ の同一条件になるよう に調整して評価した。また，この際の焼成膜の変化 の様子を可視化するため，光学顕微鏡を用いて撮影 を行った。さらに, 耐久性確認の一環として, 上述の テストペーストにセラミック（アルミナ微粉末）を 添加（0.5，2.0，3.5，5.0wt\%）したものを用意し， $1500^{\circ} \mathrm{C} \times 1 \mathrm{~h}$ で焼成した際の焼成膜の見かけ上の比抵 抗の変化を測定した。また，熱分析装置（TMA）（島 津製作所 TMA-50H）にて各白金粉末の焼成収縮挙動

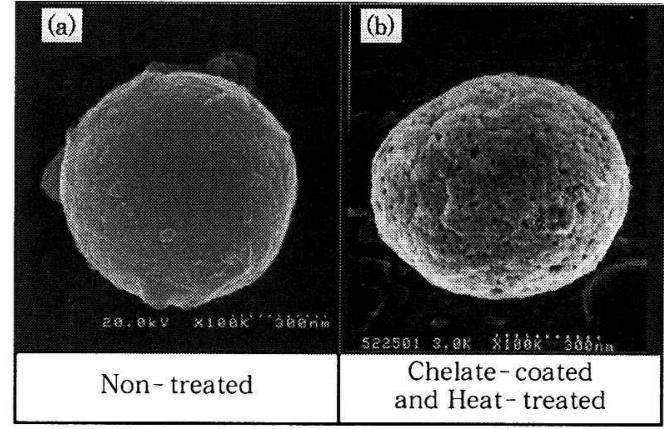

Fig. 2 SEM micrographs of Pt surfaces も評価した。

\section{3. 結果と考察}

\section{1 キレート被覆熱処理白金粉末の試作結果}

Fig. 2 に，粉末の拡大（100k 倍）SEM 図を示す。 この写真から，キレート被覆熱処理では，白金粒子の 回りに金属酸化物微粒子が被覆されている様子がうか がえる。粉末表面にところどころに見られる孔は熱処 理時に粉末内のガスが抜けた際に形成されたものであ
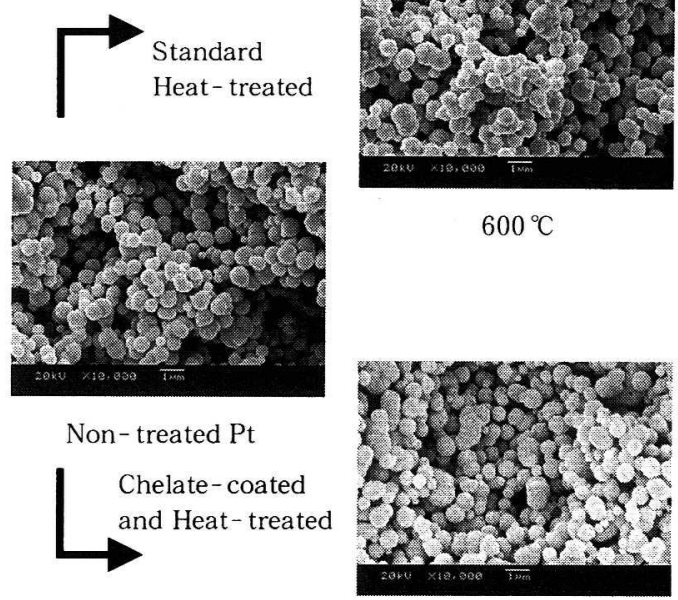

$600{ }^{\circ} \mathrm{C}$

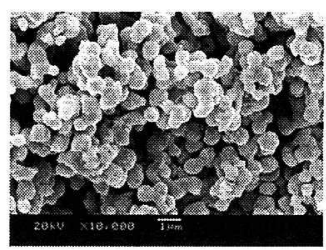

$700^{\circ} \mathrm{C}$

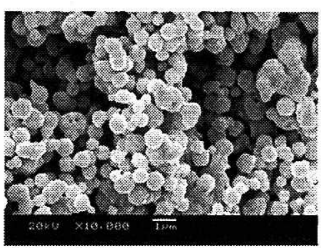

$700{ }^{\circ} \mathrm{C}$

Fig. 3 SEM micrographs of $\mathrm{Pt}$ particles after heat-treatment 

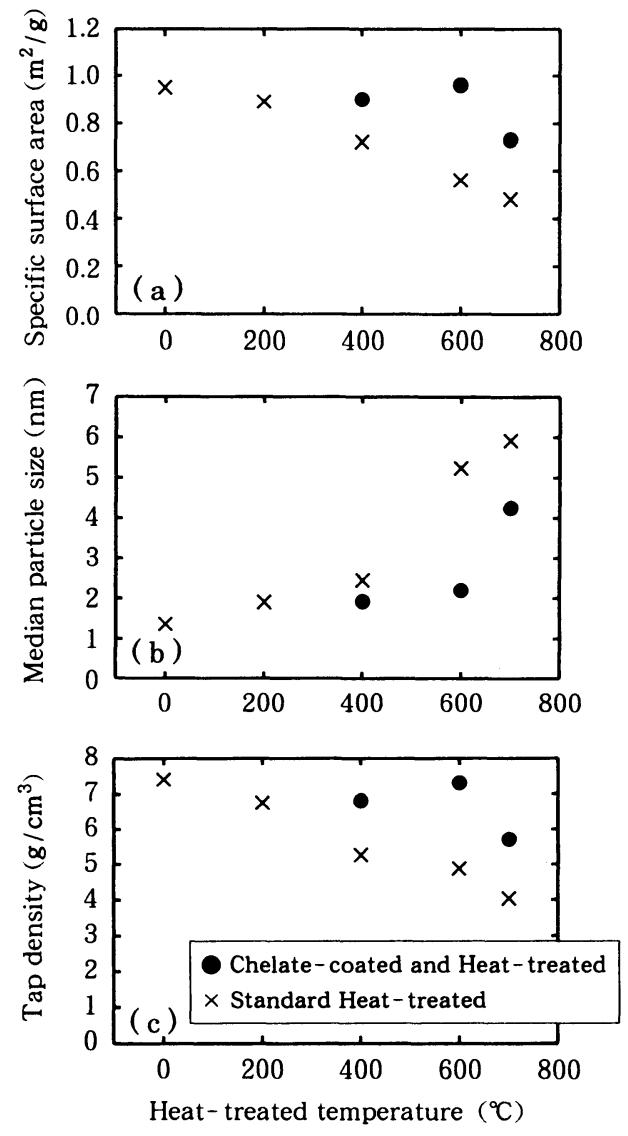

Fig. 4 Physical properties of $\mathrm{Pt}$ particle

(a) Specific surface area

(b) Median particle size

(c) Tap density

ると考えられる。

\section{2 粉末特性評価結果}

\section{2.1 分散性評価結果}

Fig. 3 に，各条件にて作製した白金粉末の SEM 写 真を示す。キレート被覆熱処理白金粉は通常熱処理白 金粉と比較すると, $600{ }^{\circ} \mathrm{C}$ の熱処理条件でもネッキ ング等で疑集した粒子が少ないことが分る。これは表 面に金属キレートを覆うことにより白金粒子同士の ネッキングを制御した効果が現れていると考える。こ のことは, Fig. 4 (a),（b),（c) で示す比表面積, 平 均粒子径, タップ密度の值からもうかがえる。

Fig. 4 (a) に熱処理温度による比表面積の変化を示 す。一般に粒子径が大きいほど比表面積は小さくな る。通常熱処理の場合, 元粉に対して温度を上げるこ とによって比表面積が小さくなる。これは温度が上昇 するにつれ白金の粒成長が促進されネッキングが起

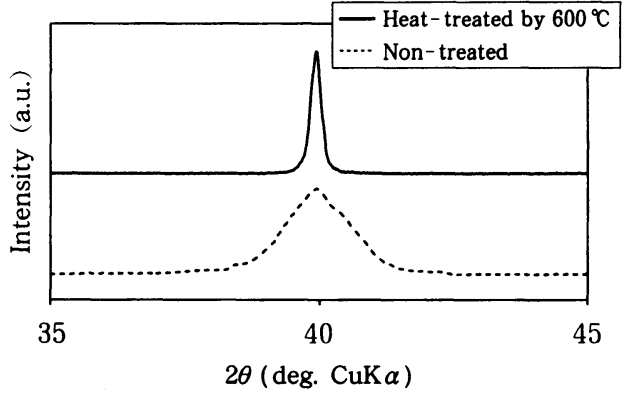

Fig. 5 XRD chart before/after heat-treatment

き，粉末の粒子径が大きくなったためだと考えられ る。このことは, Fig. 4 (b) に示す熱処理温度と粒子 径の関係で確認できる。通常熱処理白金粉では温度が 上昇するにつれレーザー回折式粒度分布測定装置で測 定した粒子径（メジアン径）が顕著に大きくなってい る。それに対し，キレート被覆熱処理の場合, 温度が 上昇しても比表面積はそれほど変化しない。これは粒 子同士のネッキングが抑制されているためと考えら れ, 粒子径の変化も通常熱処理に比べ小さい。また,

Fig. 4 (c) には熱処理温度によるタップ密度の変化を 示す。この結果からも, 通常熱処理粉では温度が上昇 するにつれ粒子間のネッキングが起きるため充塡性が 低下するのに対し，キレート被覆熱処理ではネッキン グが抑制されているため充坫性の低下は見られない。 この結果より，キレート被覆熱処理によって白金粒子 表面を覆った金属酸化物微粒子の影響で, 粉末の耐熱 性が向上したと考えることが出来る。しかしながら， 熱処理温度を $700{ }^{\circ} \mathrm{C}$ まで上げると, 両者とも粒子間 のネッキングが多く確認され, 本開発の効果は発揮さ れないことが分った。以上より，キレート被覆熱処理 を $400^{\circ} \mathrm{C} \sim 600^{\circ} \mathrm{C}$ の温度領域で行うことで, 白金粉 末のネッキング開始温度を遅らせることができ, 分散 状態の良好な白金粉末が得られることを確認した。

\section{2.2 結晶性評価結果}

Fig. 5 に，白金粉末の熱処理前と後の白金のメイン ピーク (40 付近) の XRD パターンを示す。熱処理 によってXRD の回折ピークがシャープになってお り, 白金粉末の結晶化, 粒成長が促進されていること がうかがえる。また, 通常熱処理粉末とキレート被覆 熱処理粉末によるXRD パターンの差異は見受けられ なかった。また, 半值幅から結晶子サイズを測定し た。Fig. 6 に，熱処理温度と結晶子サイズの関係を示 す。求めた結晶子サイズの值は, 熱処理前: $10 \mathrm{~nm}$, $600{ }^{\circ} \mathrm{C}$ 通常熱処理後: $62 \mathrm{~nm}, 600^{\circ} \mathrm{C}$ キレート熱処理 


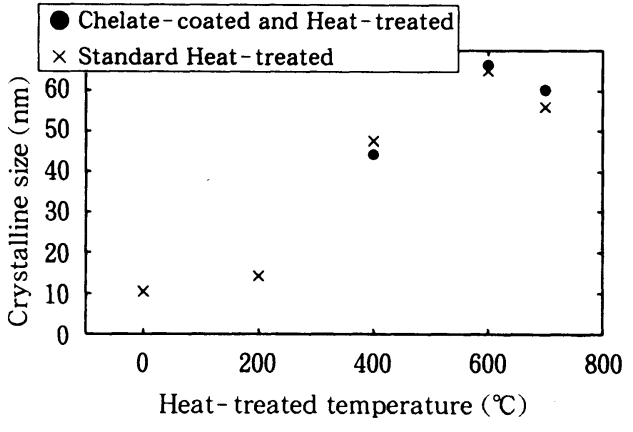

Fig. 6 Crystalline size of Pt particles

後: $65 \mathrm{~nm}$ であり, $600^{\circ} \mathrm{C}$ の温度を加えることで結晶 子サイズは約 6 倍となることが分った。

この結果により, 温度を上げることにより結晶性が 上がることが分かる。しかしながら， $600{ }^{\circ} \mathrm{C}$ 以上で は逆に結晶性が下がる。よって, 最適熱処理温度は $600^{\circ} \mathrm{C}$ と判断できる。また, 通常熱処理とキレート 熱処理による結晶性の温度依存性に䫓著な差異は認め られず，金属キレートを被覆することが, 熱処理によ る粒子の結晶性向上に悪影響を及ぼすことはほぼない と言える。次に，TG 測定によりガス抜けによる減量 を評価した。その結果を Fig. 7 に示す。未熱処理の液 相還元法白金粉末では, $500 \sim 700^{\circ} \mathrm{C}$ 付近にかけて $1 \mathrm{wt} \%$ 以上の急激な重量減が見られる。この間に, 粒子内部に内包されていた成分がガスとして抜け出た ことが分かる。一方，熱処理を行った白金粉末からは ガス抜けによる減量はほとんど確認されず，白金粉末 に吸着されるガスがほとんどないことがうかがえる。 これは，熱処理を行うことで吸着ガスは脱離し，ま た, 粒子内部では粒成長が起き, 結晶性が高まり緻密 質になるため, 再度ガスが吸着することが無くなった ものと考えられる。緻密質になったことは, 真比重 值の変化（熱処理前: $19.5 \mathrm{~g} / \mathrm{cm}^{3}$, 熱処理後 $21.4 \mathrm{~g}$ / $\mathrm{cm}^{3}$ ) から確認できる。以上より，キレート被覆熱処

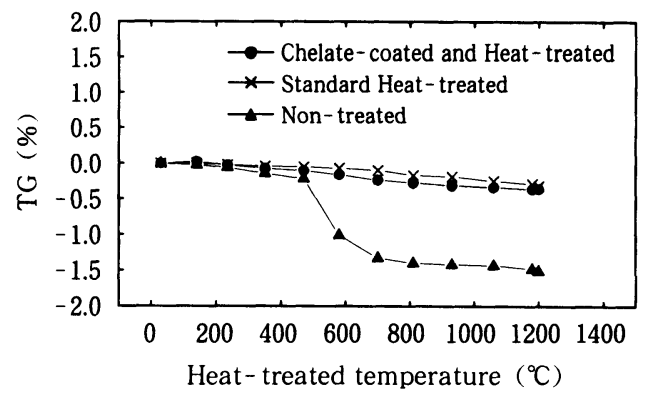

Fig. 7 TG weight change of $\mathrm{Pt}$ particles

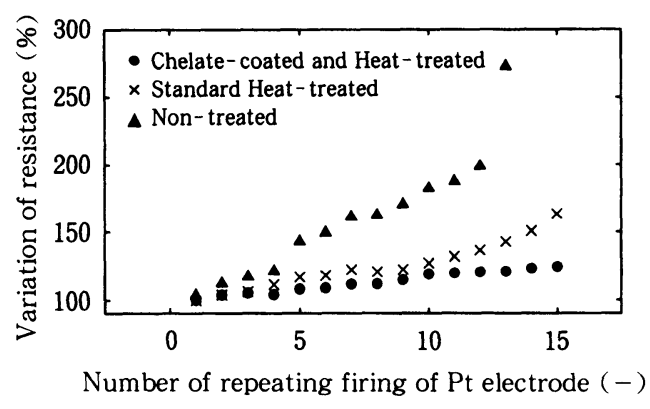

Fig. 8 Variation of resistance ratio on repeating firing

理を行うことで，分散性を維持したまま，ガス脱離が 少なく高結晶で高密度な白金粉末が得られることを確 認した。

\section{3 ペースト評価結果}

未熱処理粉末, 通常熱処理粉末, キレート被覆熱処 理粉末の各白金粉末を用いてペーストを作製し，セラ ミック基板上にスクリーン印刷し，焼成して白金電極 膜を形成した。耐久性の評価のため, 形成した抵抗発 熱体層に対して $1500{ }^{\circ} \mathrm{C}, 1 \mathrm{~h}$ での加熱処理を繰り返 し，抵抗值の変化率を測定した結果を Fig. 8 に示す。 未熱処理粉では顕著に抵抗值の変化が認められ, 13 回目で断線した。また, 通常熱処理粉でも抵抗値の変 化が認められ，15回の加熱処理で抵抗值が $60 \%$ 上昇 した。一方，キレート被覆熱処理粉は抵抗值の上昇は わずか $20 \%$ にとどまり，断線することなく高い耐久 性を示すことが確認できた。透過光を用いて撮影した 白金電極膜の光学顕微鏡写真を Fig. 9 (a) 〜 (f) に示 す。

これらの写真は白色の部分がアルミナ基板に, 黒色 部分が白金で形成された電極に対応している。Fig. 9 （a）（b）は未熱処理白金粉末を用いて形成した電極 膜を $1500^{\circ} \mathrm{C}, 1 \mathrm{~h} て ゙ 10$ 回, 15 回と繰り返し焼成した 後の透過光写真を表している。黒色の電極内に多数存 在する白色部分は, 加熱によって白金が蒸発してアル ミナ部分か露出させられたピンホールであり, 繰り返 すことによりピンホール部が大きくなり導通がとれな くなっていることが分る (Fig. 9 (b) ではパターンの 一部が断たれ断線している)。これは，未熱処理白金 粉より発生される吸着ガスが成膜段階で脱離すること により, 発泡, 歪みが起きることで焼成膜に粗密部分 ができ，その踈の部分が耐熱不足となってこのような ピンホールが生じたものと思われる。通常熱処理粉末 （Fig. 9 (c)，(d) の場合, 初期よりピンホールが多 く, 繰り返し加熱することによりそのピンホール部が 


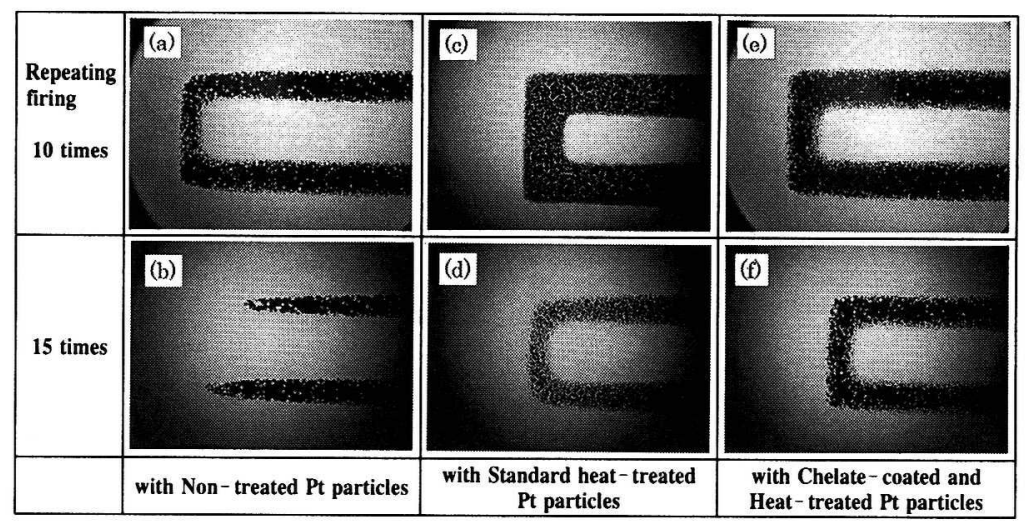

Fig. 9 Photographs with back-light of $\mathrm{Pt}$ electrode after repeating firing

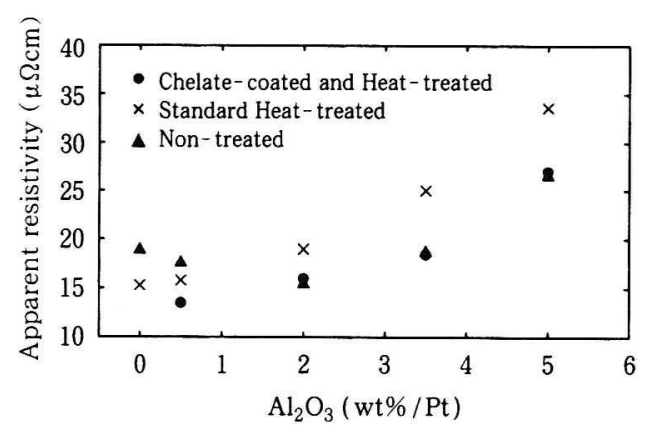

Fig. 10 Apparent resistivity of Pt electrodes

大きくなり導通する面樍が減少していることが分る。 熱処理を行うとガスによる発泡は抑制できるが，粉末 の分散性が悪くなるため, 初期より粗密部分が多い膜 となりピンホールが多く存在するようになると思われ る。それに対して, キレート被覆熱処理白金粉末 (Fig. 9 (e)，(f)) を用いて形成した電極では，ガス脱 離や分散不良といった問題は少ないため，そのような ピンホール部は少なく, 比較すると導通面積が繰り返 し加熱処理しても確保されていることが分る。この変 化はFig. 8 の抵抗值変化の結果と良く対応してい る。これらの結果より, 本研究で開発したキレート被 覆熱処理白金粉末を用いた白金ペーストは， $1500^{\circ} \mathrm{C}$ のような高温で加熱をしても膜質变化や導電性，抵抗 性の変化が生じにくい高耐久な電極膜を形成できるこ とが分った。また，耐久性の別の方法として，白金 ペーストにアルミナ微粉末を添加して作製したペース 卜を用いて形成した焼成膜の見かけ上の比抵抗を測定 した。Fig. 10 に，アルミナ微粉末の添加量と焼成膜 の見かけ上の比抵抗の関係を示す。一般的にペースト 中に耐熱性の高いセラミック（本試験ではアルミナ微 粉末を添加）を添加すると, 白金粒子の隙間にセラミ

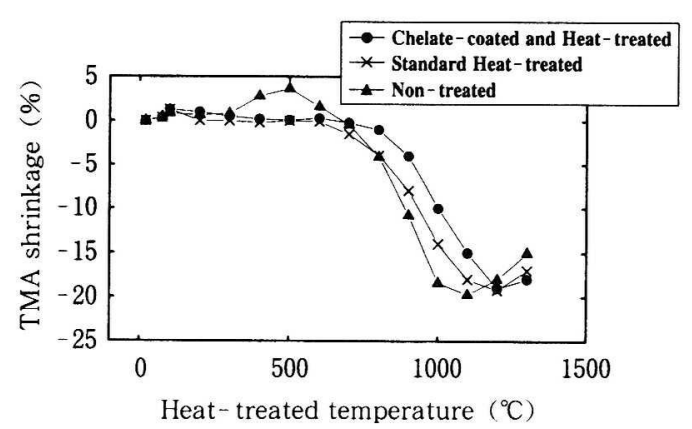

Fig. 11 TMA shrinkage of $\mathrm{Pt}$ pastes

ックが充塡されることで焼結が抑制され，焼成膜の連 続性が低下し比抵抗は高くなることが知られている。 Fig. 10 よりアルミナ微粉末を多く添加 (2.0wt \% 以 上）した場合，通常熱処理白金粉末を用いて形成した 焼成膜は，より顕著に比抵抗が高くなることが分か る。これは，通常熱処理粉末は白金粒子同士のネッキ ングが多いため，緻密な焼成膜を形成できないことを 示している。一方，キレート被覆熱処理白金粉末を用 いて形成した焼成膜は，分散性の良い未熱処理白金粉 末を用いて形成した焼成膜と同等の比抵抗を示すこと が分かる。このことからも，金属キレート被覆による 白金粒子同士のネッキング抑制効果が確認できる。ま た，アルミナ微粉末が少ない（2.0wt％以下）之未熱 処理白金粉末を用いて形成した膜では，耐熱性不足に より焼結が早く進行し，過焼結状態となる。よって， ピンホールが多く発生し，焼成膜の連続性が低下する ため比抵抗が高くなる。一方，キレート被覆熱処理 粉末を使用した場合，粉末が耐熱性を有するため焼 成膜の連続性が高くなり，その結果，比抵抗は小さく なる。

また，Fig. 11 には，各ペーストの熱収縮曲線を示 


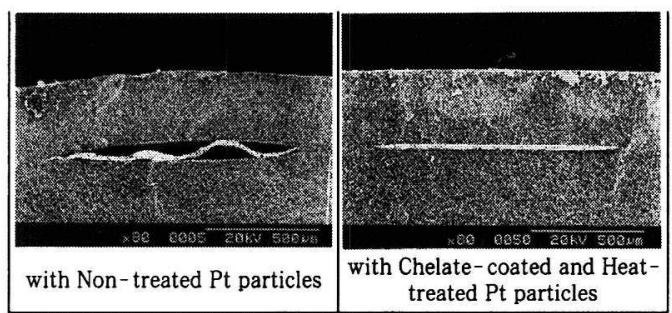

Fig. 12 Photographs of cross section of $\mathrm{Pt}$ electrode fired by $1500{ }^{\circ} \mathrm{C}$

す。熱処理を行った 2 種の粉末では， $500^{\circ} \mathrm{C}$ 付近の 脱ガスに伴う膨張がなくなっていることが分る。ま た，キレート被覆熱処理粉末を用いたペーストは収縮 開始温度が高くなり，耐熱性が向上していることが分 かる。耐熱性が向上したことで素体となるセラミック （例えばアルミナ）グリーンシートとの焼結挙動と近 くなり，同時焼成しても構造欠陥が起こりにくいとい った大きな効果も得られた。Fig. 12 に，実際にセラ ミックグリーンシートと白金ペーストを同時焼成した
積層焼成体の断面状態を示す。中央の白い層が白金電 極膜の層で，その両側を挟んでいるのがセラミックの 層である。未熱処理白金粉末を用いて形成した電極膜 では，セラミックと白金電極膜の焼成収縮のミスマッ チにより, 密着性が低下し剥離が生じている。一方, キレート被覆熱処理の場合, セラミックとの密着性が 非常に良好であることがこの図からもよく分る。

\section{4. 結言}

白金粉末に対してのキレート被覆熱処理技術によ り，白金粉末同士のネッキングを抑制し，分散性を維 持しつつ, 高結晶でガス脱離のないPt 粉末の開発に 成功した。その粉末を用いたペーストは, 加熱をして も膜質変化や導電性，抵抗性の変化が生じにくい高耐 久性の抵抗発熱体層を形成することができ，また，素 体となるセラミック（例えばアルミナ）との焼結挙動 と近くなることで, 同時焼成しても構造欠陥が起こり にくい効果も確認できた。

\section{References}

1) Izu, N., W. Shin, I. Matsubara and N. Murayama : "Comparison of sensitivity of resistive oxygen sensors using Pt electrodes prepared by screen-printing and sputtering with metal mask ${ }^{n}$, Electrochemistry, 73, 502-504 (2005)

2 ) Garcia, R. V., A. R. Serrano, M. A. Hernandez, F. C. Alcala and C. G. Yanez: "Pt electrode-based sensor prepared by metal organic chemical vapor deposition for oxygen activity measurements in glass melts", Sensors and Materials, 14, 47-56 (2002)

3) Usmen, R. K., E. M. Logothetis and M. Shelef : "Measurement of $\mathrm{Pt}$ electrode surface area of automotive $\mathrm{ZrO}_{2}$ oxygen sensors", Sensors and Actuators, B : Chemical, B28, 139-142 (1995)

4 ) Ueyama, R., K. Kamada, M. Harada and T. Ueyama: "Low temperature synthesis of silver-palladium alloy powders internal electrodes for multilayer ceramic devices”, J. Materials Sci., 36, 371-379 (2001)

5 ) Ueyama, R., T. Ueyama and K. Koumoto: "Effect of particle size on electrode paste properties and sintering properties of $\mathrm{Ni}$ powder synthesized by wet chemical process”, J. Ceram. Soc., Japan, 108, 769-773 (2000)

6 ) Iida, N., K. Nakayama, I. W. Lenggoro and K. Okuyama: "Preparation and Application of Au/Ag Alloy Particles by Spray Pyrolysis Method", J. Soc. Powder Technol. Japan, 41, 246-251 (2004)

7 ) Lenggoro, I. W., T. Hata, F. Iskandar, M. M. Lunden and K. Okuyama: “An Experimental and Modeling Investigation of Particle Production by Spray Pyrolysis Using A Laminar Flow Aerosol Reactor”, J. Mater. Res., 15, 733-743 (2000) 